\title{
Morphological variability, density and yield of Trifolium repens in different ecological and coenotic conditions
}

\author{
Galina Demina, Nina Prokhorenko* , and Luiza Kadyrova \\ Kazan Federal University, 420008, Kremlyovskaya str., 18, Kazan, Russian Federation
}

\begin{abstract}
White clover (Trifolium repens L.) is a valuable melliferous, pasture and a promising species for use as a medicinal raw materials. $T$. repens herb contains ascorbic acid, carotene, alkaloids, glycosides and other substances. Fourteen coenopopulations of T. repens were studied on the territory of the Republic of Tatarstan. The assessment of habitats of $T$. repens was carried out by indicator methods using the ecological scales of G. Ellenberg. The density of coenopopulations, comparative morphometric analysis and reserves of dry aboveground biomass are analyzed in this article. It was found that the soils in the subtaiga subzone are weakly acidic, fresh in terms of moisture, with a nitrogen content above average; soils in the north of the broad-leaved subzone are dry and periodically fresh, with a slightly acidic reaction and an average content of mineral nitrogen; and the soils in the south of the broad-leaved subzone are dry and periodically fresh, predominantly neutral, with a nitrogen content above average. A comparative analysis of the scoring of soil characteristics with the content of the main nutrients in the soil has been carried out. T. repens coenopopulations in the north of the broad-leaved subzone have of low density, and high biomass shoots are formed. The yield of the studied $T$. repens plants is from $21-178 \mathrm{~kg}$ of dry weight/ha. The highest yields of dry aboveground biomass of plants was observed in the northern deciduous subzone. We recommend the highest-yielding coenopopulations of $\mathrm{T}$. repens for harvesting plant material.
\end{abstract}

\section{Introduction}

White clover (Trifolium repens L.) is a summer-winter-green or summer-green herbaceous perennial polycarpous plant with elongated creeping sympodially growing shoots. White clover has a Euro-Asian distribution, being found in wet meadows, forest edges, waterfronts and near roads. White clover as a representative of the Fabaceae family ensures the accumulation of nitrogen in the soil from 110 to $545 \mathrm{~kg} / \mathrm{ha}$ per year, which allows its usage in mixtures with other forage plants to maintain high pasture productivity and increasing the productivity of cultivated plants. [1,2,3]. This species can also be used in landscape design as an unpretentious ground cover plant due to its high ability for radial growth of shoots, vegetative propagation with the help of particulation, as well as the

\footnotetext{
*Corresponding author: nbprokhorenko@mail.ru
} 
explerent (explorative) life strategy [4]. White clover can be used as a medicinal plant raw material, since ascorbic acid, carotene, glycosides, flavanoids and other substances were found in the aerial parts $[5,6,7]$.

The Republic of Tatarstan covers four landscape subzones: the southern taiga and subtaiga subzones as part of the boreal landscape zone, as well as broad-leaved and foreststeppe subzones as part of the subboreal northern semihumid landscape zone [8]. Identification of adaptive mechanisms to the habitat conditions of economically significant plants on the territory of the Republic of Tatarstan is relevant.

Aim of the study was to determine the variability of the morphological status of plants, the density of coenopopulations and the yield of dry aboveground phytomass of white clover in different landscape subzones and different habitats within the Republic of Tatarstan.

\section{Methods}

The collection of material was carried out during the growing season 2018-2020 on the territory of six administrative districts of the Republic of Tatarstan. Fourteen coenopopulations (CPs) of white clover were studied as part of meadow, forest, forest edge and roadside communities: CPs 1, 2, 3 and 4 (Zelenodolsk and Baltasinsky district) are located in the subtaiga subzone, CP 5 and 6 (Laishevsky district) and CPs 7, 8, 9 and 10 (Verkhneuslonskiy district) are in the north of the deciduous subzone, while CPs 11, 12 and 13 (Tetyushsky district) are in the south of the broad-leaf subzone at the point of contact with the forest-steppe subzone, CP 14 (Aktanyshsky district) are in the forest-steppe subzone (Table 1).

In various phytocenoses, geobotanical descriptions were carried out, and five plots of 1 $\mathrm{m}^{2}$ were laid, where all white clover plants were dug out for herbarization and the morphometric analysis. In the process of morphological study, metric and allometric parameters of generative shoots were determined in dried plants: length $(\mathrm{L}, \mathrm{cm})$, dry biomass (W, g), biomass of leaves (WL, g), number of inflorescences (heads) per shoot (NI, pcs.), inflorescence biomass (WG, g), number of flowers per inflorescence (NF, pcs.), and number of flowers per shoot $(\mathrm{NF} / \mathrm{sh}$, pcs.), reproductive effort $(\mathrm{RE}=\mathrm{WG} / \mathrm{W})$ and photosynthetic effort $(\mathrm{LWR}=\mathrm{WL} / \mathrm{W})$. All morphometric data and density values were processed statistically in Excel. The significance of differences between the mean values was assessed using the Student's coefficient at a 5\% significance level. The shoot was chosen as a counting unit for statistical analysis and estimation of coenopopulations density (Table 1). The sample size of the studied CPs ranged from 8 to 91 plants. The correlation analysis was carried out to identify the relationship between metric and allometric parameters with the density index.

The yield in different habitats was determined by summing up the air-dry aboveground phytomass of generative shoot collected from 5 meter plots.

The habitat conditions of white clover were assessed by indicator methods using six point ecological scales of G. Ellenberg: illumination (L), temperature regime (T), climate continentality $(K)$, soil moisture $(F)$, soil acidity $(R)$, and soil nitrogen richness $(N)$ [9]. The values of ecological factors for the habitat of each $\mathrm{CP}$ were calculated using the EcoScaleWin program. 
Table 1. Trifolium repens L. coenopopulations (CPs) studied here (the Tatarstan Republic).

\begin{tabular}{|c|c|c|c|}
\hline $\begin{array}{c}\text { Landscape subzone / } \\
\text { CP }\end{array}$ & Coordinates & Phytocenosis type & $\begin{array}{c}\text { Sample size, } \\
\text { generative } \\
\text { shoots pcs. }\end{array}$ \\
\hline Subtaiga (north) / CP 1 & $\begin{array}{l}56^{\circ} 44^{\prime} 19^{\prime \prime} \mathrm{N} \\
50^{\circ} 25^{\prime} 95^{\prime \prime} \mathrm{E}\end{array}$ & $\begin{array}{l}\text { Pinetum } \\
\text { nemoroherbosum edge }\end{array}$ & 49 \\
\hline Subtaiga (south) / CP 2 & $\begin{array}{l}55^{\circ} 83^{\prime} 68^{\prime \prime} \mathrm{N} \\
48^{\circ} 78^{\prime} 53^{\prime \prime} \mathrm{E} \\
\end{array}$ & $\begin{array}{c}\text { Querco-Tilietum } \\
\text { nemoroherbosum edge }\end{array}$ & 66 \\
\hline Subtaiga (south) / CP 3 & $\begin{array}{l}55^{\circ} 83^{\prime} 80^{\prime \prime} \mathrm{N} \\
48^{\circ} 76^{\prime} 97^{\prime \prime} \mathrm{E} \\
\end{array}$ & $\begin{array}{c}\text { Querco-Tilietum } \\
\text { nemoroherbosum edge }\end{array}$ & 66 \\
\hline Subtaiga (south) / CP 4 & $\begin{array}{l}55^{\circ} 84^{\prime} 34^{\prime \prime} \mathrm{N} \\
48^{\circ} 73^{\prime} 90^{\prime \prime} \mathrm{E} \\
\end{array}$ & $\begin{array}{c}\text { Querco-Tilietum } \\
\text { nemoroherbosum edge }\end{array}$ & 91 \\
\hline Broadleaf (north) / CP 5 & $\begin{array}{l}55^{\circ} 53^{\prime} 36^{\prime \prime} \mathrm{N} \\
49^{\circ} 12^{\prime} 40^{\prime \prime} \mathrm{E} \\
\end{array}$ & $\begin{array}{c}\text { Betuletum } \\
\text { nemoroherbosum }\end{array}$ & 8 \\
\hline Broadleaf (north) / CP 6 & $\begin{array}{l}55^{\circ} 53^{\prime} 60^{\prime \prime} \mathrm{N} \\
49^{\circ} 15^{\prime} 37^{\prime \prime} \mathrm{E} \\
\end{array}$ & Roadside & 42 \\
\hline Broadleaf (north) / CP 7 & $\begin{array}{l}55^{\circ} 5805^{\prime \prime} \mathrm{N} \\
48^{\circ} 9693^{\prime \prime} \mathrm{E}\end{array}$ & $\begin{array}{c}\text { Festucetum } \\
\text { varioherbosum }\end{array}$ & 33 \\
\hline Broadleaf (north) / CP 8 & $\begin{array}{l}55^{\circ} 61^{\prime} 22^{\prime \prime} \mathrm{N} \\
48^{\circ} 95^{\prime} 09^{\prime \prime} \mathrm{E} \\
\end{array}$ & $\begin{array}{c}\text { Festucetum } \\
\text { varioherbosum }\end{array}$ & 23 \\
\hline Broadleaf (north) / CP 9 & $\begin{array}{l}55^{\circ} 53^{\prime} 30^{\prime \prime} \mathrm{N} \\
48^{\circ} 97^{\prime} 98^{\prime \prime} \mathrm{E} \\
\end{array}$ & $\begin{array}{c}\text { Festucetum } \\
\text { varioherbosum }\end{array}$ & 74 \\
\hline Broadleaf (north) / CP 10 & $\begin{array}{l}55^{\circ} 77^{\prime} 01^{\prime \prime} \mathrm{N} \\
48^{\circ} 71^{\prime} 66^{\prime \prime} \mathrm{E}\end{array}$ & Roadside & 84 \\
\hline Broadleaf (south) / CP 11 & $\begin{array}{l}54^{\circ} 96^{\prime} 45^{\prime \prime} \mathrm{N} \\
48^{\circ} 82^{\prime} 76^{\prime \prime} \mathrm{E} \\
\end{array}$ & $\begin{array}{l}\text { Calamagrostetum } \\
\text { varioherbosum }\end{array}$ & 70 \\
\hline Broadleaf (south) / CP 12 & $\begin{array}{l}55^{\circ} 05^{\prime} 61^{\prime \prime} \mathrm{N} \\
48^{\circ} 93^{\prime} 35^{\prime \prime} \mathrm{E} \\
\end{array}$ & $\begin{array}{c}\text { Festucetum } \\
\text { varioherbosum }\end{array}$ & 64 \\
\hline Broadleaf (south) / CP 13 & $\begin{array}{l}55^{\circ} 10^{\prime} 10^{\prime \prime} \mathrm{N} \\
49^{\circ} 00^{\prime} 92^{\prime \prime} \mathrm{E}\end{array}$ & $\begin{array}{c}\text { Festucetum } \\
\text { varioherbosum }\end{array}$ & 87 \\
\hline $\begin{array}{c}\text { Forest-steppe subzone / } \\
\text { CP } 14\end{array}$ & $\begin{array}{l}55^{\circ} 71^{\prime} 09^{\prime \prime} \mathrm{N} \\
54^{\circ} 05^{\prime} 81^{\prime \prime} \mathrm{E} \\
\end{array}$ & $\begin{array}{c}\text { Festucetum } \\
\text { varioherbosum }\end{array}$ & 64 \\
\hline
\end{tabular}

\section{Results}

The investigated of white clover CPs in the subtaiga subzone are part of the forest edge communities, in the subzone of deciduous forests and forest-steppe - Festucetum varioherbosum and Calamagrostetum varioherbosum meadows. The calculation of values of ecological factors by indicator methods for the species composition of phytocenoses showed that the habitats of the white clover CPs have illumination (L) in the range of 6.97.9 points, which characterizes the conditions as half-shade or almost completely illuminated (illumination of $\geq 50 \%$ of full) (Table 2). Among the climatic parameters, the temperature regime $(\mathrm{T})$ varies from 5.65 to 5.98 points and the continentality of climate $(\mathrm{K})$ is from 3.58 to 4.89 points, which indicates the conditions of a moderately warm, from suboceanic to weakly subcontinental climate. Soil moisture (F) varies from 4.3 to 5.1 points, that characterizes them as dry periodically fresh and fresh. The point values of soil acidity vary from 6.1 to 7.06 , which defines them as slightly acidic or neutral. The point values of mineral nitrogen supply are in the range from 4.46 to 5.45 and indicate an average or above average nitrogen content. 
Table 2. Scoring of environmental factors on the basis of G. Ellenberg's ecological scales in Trifolium repens L. CPs (the Tatarstan Republic).

\begin{tabular}{|l|c|c|c|c|c|c|}
\hline \multirow{2}{*}{ Landscape subzone / CP } & \multicolumn{5}{|c|}{ Values of environmental factors (points) } \\
\cline { 2 - 7 } & L & T & K & F & R & N \\
\hline Subtaiga (north) / CP 1 & 7.15 & 5.75 & 3.91 & 4.38 & 6.58 & 3.85 \\
\hline Subtaiga (south) / CP 2 & 7.03 & 5.65 & 4.03 & 4.87 & 6.01 & 5.22 \\
\hline Subtaiga (south) / CP 3 & 7.2 & 5.72 & 4.28 & 4.76 & 6.31 & 5.06 \\
\hline Subtaiga (south) / CP 4 & 7.32 & 5.92 & 4.66 & 5.1 & 6.76 & 5.8 \\
\hline Broadleaf (north) / CP 5 & 6.91 & 5.7 & 3.58 & 4.64 & 6.7 & 4.82 \\
\hline Broadleaf (north) / CP 6 & 7.51 & 6.0 & 4.32 & 4.45 & 6.33 & 4.71 \\
\hline Broadleaf (north) / CP 7 & 7.65 & 5.91 & 4.41 & 4.34 & 6.85 & 4.97 \\
\hline Broadleaf (north) / CP 8 & 7.44 & 5.86 & 4.51 & 4.56 & 7.02 & 4.99 \\
\hline Broadleaf (north) / CP 9 & 7.9 & 5.91 & 4.89 & 4.38 & 7.06 & 5.26 \\
\hline Broadleaf (north) / CP 10 & 7.4 & 5.73 & 4.51 & 4.9 & 7.1 & 5.43 \\
\hline Broadleaf (south) / CP 11 & 7.74 & 5.94 & 4.67 & 4.57 & 7.1 & 5.45 \\
\hline Broadleaf (south) / CP 12 & 7.4 & 5.77 & 3.82 & 4.7 & 6.74 & 5.23 \\
\hline Broadleaf (south) / CP 13 & 7.42 & 5.98 & 4.21 & 4.3 & 7.1 & 4.46 \\
\hline Forest-steppe subzone / CP 14 & - & - & - & - & - & - \\
\hline
\end{tabular}

The habitat conditions of white clover in the subtaiga subzone are characterized by slightly acidic, fresh and above average nitrogen-supplied soils. In the subzone of deciduous forests, soils are periodically dry fresh with a mineral nitrogen content ranging from average (in the north of the subzone) to above average (in the south of the subzone). At the same time, the acidity of the soils decreases in the direction from the subtaiga to the south of the broad-leaved subzone.

These observations are also confirmed by the methods of traditional soil research in terms of nutrient content, $\mathrm{pH}$ of salt extract, and humus. The data are given in Table 3.

Table 3. The content of the main nutrients in the soil.

\begin{tabular}{|c|c|c|c|c|c|c|c|c|}
\hline 1 & 2 & 3 & 4 & 5 & 6 & 7 & 8 & 9 \\
\hline CP 1 & - & - & - & - & - & - & - & - \\
\hline CP 2 & 6.8 & 3.2 & 3.6 & 13.0 & 80 & 160 & 28.5 & 2.5 \\
\hline CP 3 & 6.7 & 3.2 & 3.8 & 13.1 & 77 & 162 & 28.4 & 2.4 \\
\hline CP 4 & 6.7 & 1.6 & 5.4 & 17.0 & 64 & 356 & 9.8 & 2.75 \\
\hline CP 5 & 6.4 & 2.7 & 16.6 & 14.5 & 135 & 190 & 15.0 & 3.75 \\
\hline CP 6 & - & - & - & - & - & - & - & - \\
\hline CP 7 & 6.5 & 2.1 & 3.7 & 11.0 & 37 & 65 & 19.0 & 3.25 \\
\hline CP 8 & 6.3 & 2.5 & 6.3 & 10.9 & 250 & 266 & 10.0 & 6.75 \\
\hline CP 9 & 6.5 & 1.5 & 5.6 & 10.9 & 22 & 464 & 22.5 & 5.0 \\
\hline CP 10 & 6.3 & 2.5 & 5.5 & 10.4 & 146 & 195 & 26.3 & 4.5 \\
\hline CP 11 & 7.2 & 2.0 & 19.5 & 9.1 & 35 & 444 & 19.5 & 7.25 \\
\hline CP 12 & 6.0 & 1.7 & $>2.8$ & 11.0 & 264 & 170 & 13.8 & 3.25 \\
\hline CP 13 & 7.0 & 2.3 & 8.2 & 16.4 & 99 & 73 & 20.0 & 7.25 \\
\hline CP 14 & - & - & - & - & - & - & - & - \\
\hline
\end{tabular}

Note: 1 - soil sample from habitat; 2 - $\mathrm{pH} ; 3$ - humus, $\% ; 4$ - nitrate nitrogen, $\mathrm{mg} / \mathrm{kg} ; 5$ - ammonia nitrogen, $\mathrm{mg} / \mathrm{kg} ; 6$ - mobile phosphorus, $\mathrm{mg} / \mathrm{kg} ; 7$ - exchangeable potassium, $\mathrm{mg} / \mathrm{kg} ; 8$ - exchangeable calcium, mmol/100 g; 9 - exchangeable magnesium, mmol/100 g.

Comparison of the values of ecological scales and the traditional index $\mathrm{pH}$ of salt extract revealed similar results: in all habitats, the reaction of the soil is weakly acidic or 
close to neutral. The highest content of humus and nitrate nitrogen in the soil was found in some CPs (CPs 5, 11) in the broad-leaved subzone.

The density of shoots in white clover CPs varies from 10 to $55 \mathrm{pcs} . \mathrm{m}^{2}$. The highest density of white clover shoots is typical for the south of the broad-leaved subzone, where, according to our data, the habitat conditions are characterized by the greatest illumination (above $50 \%$ of full), the soils are neutral, dry and peridically fresh with a nitrogen content above average (Fig. 1).

The lowest density of shoots, $15-30 \mathrm{pcs} . / \mathrm{m}^{2}$, was noted for the north of the broad-leaved subzone (CPs 5-10) and in the north of the subtaiga zone (CPs 1), where, according to calculations, the habitat conditions are also characterized by the illumination above $50 \%$ of the full, the soils are slightly acidic, dry, periodically fresh with an average content of mineral nitrogen.

In the subtaiga subzone, CPs of both high density (CP 3) and sparse (CP 1) are widespread, which indicates the heterogeneity of the ecological and coenotic growing conditions of white clover.

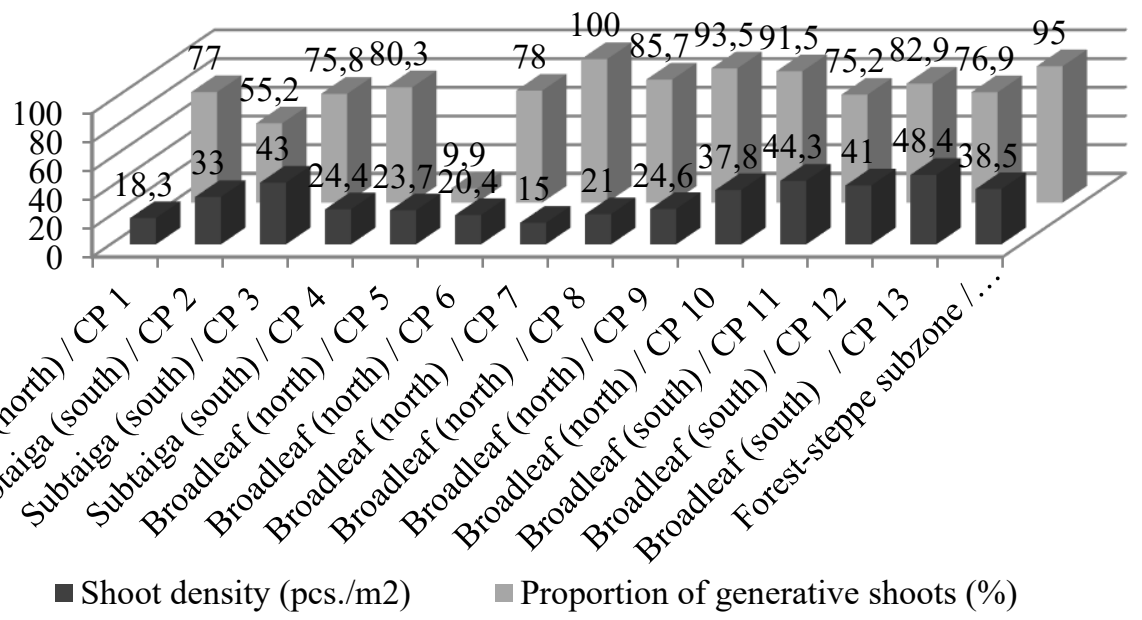

Fig. 1. Shoot density $\left(\mathrm{pcs} . / \mathrm{m}^{2}\right)$ and proportion of generative shoots (\%) in Trifolium repens L. coenopopulations on the territory of the Tatarstan Republic.

The proportion of generative shoots in white clover CPs varies from 10 to $100 \%$. In the CPs with a relatively low density (CPs 5-9) which are localized in the north of the broadleaved subzone, the greatest proportion of generative shoots is noted (more than $85 \%$, the rest are vegetative). CPs with a relatively high density of shoots in the south of the broadleaved subzone and in the subtaiga subzone, the proportion of generative shoots decreases to $50-75 \%$.

The low number of generative shoots is observed in CP 5 in the nemoral-herb birch forest due to the low illumination.

Our research has shown that, generative plagiotropic shoots of white clover have a length from 3.9 to $30.3 \mathrm{~cm}$, dry biomass from 0.15 to $0.87 \mathrm{~g}$, number of inflorescences (heads) from 1 to 2.3 pcs. per shoot, number of flowers from 16.1 to 38.9 pcs. per head, and total number of flowers (NF/sh) from 15.2 to 53 pcs. per shoot (Tables 4-6). The average values of photosynthetic effort (LWR) are 0.01-0.28 and those of reproductive effort (RE) are $0.02-0.25$.

In the subtaiga subzone, such parameters as dry phytomass of shoots and leaves and the number of inflorescences on shoot white clover have not high values. In particular, the dry 
biomass of shoot is 2-2.5 times, and the number of inflorescences is 1.5-1.9 times lower compared to the plants in the north of the broad-leaved subzone.

Table 4. Morphometric features of Trifolium repens L. generative plants in the subtaiga subzone of the Tatarstan Republic.

\begin{tabular}{|l|c|c|c|c|}
\hline \multirow{2}{*}{} & \multicolumn{4}{|c|}{$\mathbf{x} \pm \mathbf{S}_{\mathbf{x}}$} \\
\cline { 2 - 5 } & $\mathbf{C P ~ 1}$ & $\mathbf{C P ~ 2}$ & $\mathbf{C P ~ 3}$ & $\mathbf{C P ~ 4}$ \\
\hline L, cm & $8.01 \pm 1.00$ & $14.03 \pm 0.62$ & $9.45 \pm 0.41$ & $9.64 \pm 0.54$ \\
\hline W, g & $0.13 \pm 0.01$ & $0.31 \pm 0.02$ & $0.25 \pm 0.01$ & $0.22 \pm 0.02$ \\
\hline WL, g & $0.04 \pm 0.01$ & $0.08 \pm 0.01$ & $0.03 \pm 0.003^{*}$ & $0.07 \pm 0.01$ \\
\hline LWR & $0.35 \pm 0.02$ & $0.25 \pm 0.02$ & $0.15 \pm 0.02$ & $0.28 \pm 0.02$ \\
\hline NI, pc. & - & $1.08 \pm 0.03$ & $1.48 \pm 0.08$ & $1.36 \pm 0.06$ \\
\hline WG, g & $0.04 \pm 0.01$ & $0.04 \pm 0.004$ & $0.05 \pm 0.004$ & $0.07 \pm 0.005$ \\
\hline RE & $0.33 \pm 0.02$ & $0.12 \pm 0.01^{*}$ & $0.22 \pm 0.02$ & $0.33 \pm 0.02^{*}$ \\
\hline NF, pc. & $39.79 \pm 3.28$ & $38.99 \pm 1.76$ & $25.04 \pm 1.01$ & $20.12 \pm 0.92$ \\
\hline NF/sh, pc. & - & $41.52 \pm 2.21$ & $36.31 \pm 2.39$ & $27.5 \pm 1.76$ \\
\hline
\end{tabular}

*the value is significantly differs from the corresponding value of the another CPs

In the north of the broad-leaved subzone the dry biomass of shoots and leaves of white clover, as well as the total number of flowers on shoot are 1.7-3.3 times and 1.5-2 times higher, respectively, compared to the conditions of the subtaiga subzone and the south of the broad-leaved subzone (Table 4-6).

Table 5. Morphometric features of Trifolium repens L. generative plants in the broad-leaved subzones of the Tatarstan Republic.

\begin{tabular}{|l|c|c|c|c|c|}
\hline \multirow{2}{*}{} & \multicolumn{5}{|c|}{$\mathbf{x} \pm \mathbf{S}_{\mathbf{x}}$} \\
\cline { 2 - 6 } & $\mathbf{C P ~ 5}$ & $\mathbf{C P ~ 6}$ & $\mathbf{C P ~ 7}$ & $\mathbf{C P ~ 8}$ & $\mathbf{C P ~ 9}$ \\
\hline L, cm & $30.25 \pm 6.5^{*}$ & $14.39 \pm 2.1$ & $10.55 \pm 0.3$ & $9.59 \pm 0.63$ & $14.47 \pm 0.6$ \\
\hline W, g & $0.87 \pm 0.2^{*}$ & $0.19 \pm 0.03$ & $0.49 \pm 0.06^{*}$ & $0.23 \pm 0.01$ & $0.45 \pm 0.03^{*}$ \\
\hline WL, g & $0.1 \pm 0.01^{*}$ & $0.03 \pm 0.01$ & $0.02 \pm 0.01^{*}$ & $0.05 \pm 0.01$ & $0.08 \pm 0.01^{*}$ \\
\hline LWR & $0.01 \pm 0.03^{*}$ & $0.14 \pm 0.02$ & $0.06 \pm 0.01$ & $0.21 \pm 0.03$ & $0.17 \pm 0.01$ \\
\hline NI, pc. & $1.33 \pm 0.21$ & - & $2.30 \pm 0.18$ & $1.26 \pm 0.09$ & $1.71 \pm 0.09$ \\
\hline WG, g & $0.01 \pm 0.01$ & $0.03 \pm 0.00$ & $0.06 \pm 0.01$ & $0.03 \pm 0.01$ & $0.05 \pm 0.01$ \\
\hline RE & $0.02 \pm 0.01^{*}$ & $0.12 \pm 0.02$ & $0.14 \pm 0.02$ & $0.10 \pm 0.02$ & $0.13 \pm 0.01$ \\
\hline NF, pc. & $16.14 \pm 2.3$ & $20.53 \pm 3.1$ & $24.89 \pm 1.4$ & $30.83 \pm 2.2$ & $29.22 \pm 1.1$ \\
\hline NF/sh, pc. & $15.17 \pm 2.4$ & - & $57.94 \pm 6.3^{*}$ & $38.87 \pm 4.5$ & $51.6 \pm 2.97$ \\
\hline
\end{tabular}

*the value is significantly differs from the corresponding value of the another CPs

In the south of the broad-leaved subzone, white clover plants are distinguished by the presence of shortened shoots, the length of which is 1.5-3 times less than in the subtaiga subzone and in the north of the broad-leaved subzone (Table 5). In addition, in some CPs, shoots are characterized by a relatively low total biomass and biomass of leaves, the values of which are 2.5-5 times lower than in other landscape areas.

In the forest-steppe subzone, white clover plants are distinguished by a reliably high phytomass of shoots and the number of flowers in one inflorescence.

In some places of plant collection (CP 2, 3, 12), a direct dependence of dry aboveground biomass of shoots on the content of humus and nitrate nitrogen in the soil, in others (СР 5 и 9) - an inverse relationship was revealed.

The shoot biomass has a positive correlation with the shoot length $(r=0.94$, significant at $\mathrm{p}=0.01$ ), therefore, biomass accumulation occurs as shoots with a significant length are formed. The formation of shoots with a high biomass and a large number of reproductive 
organs is determined by the low density of the white clover CP and a complex of ecological-cenotic conditions in the north of the broad-leaved subzone.

The dry phytomass of white clover generative shoot was $0.12-0.87 \mathrm{~g}$, and the yield of aboveground phytomass was $20-210 \mathrm{~kg} / \mathrm{ha}$ (Table 7).

Table 6. Morphometric features of Trifolium repens L. generative plants in the broad-leaved (CPs 1013) and forest-steppe (CP 14) subzones of the Tatarstan Republic.

\begin{tabular}{|l|l|c|c|c|c|}
\hline \multirow{2}{*}{} & \multicolumn{5}{|c|}{$\mathbf{x} \pm \mathbf{s}_{\mathbf{x}}$} \\
\cline { 2 - 6 } & \multicolumn{1}{|c|}{ CP 10 } & CP 11 & CP 12 & \multicolumn{1}{|c|}{ CP 13 } & CP 14 \\
\hline L, cm & $16.45 \pm 0.6$ & $6.81 \pm 0.43^{*}$ & $3.99 \pm 0.26^{*}$ & $5.01 \pm 0.23^{*}$ & $27.26 \pm 1.33$ \\
\hline W, g & $0.50 \pm 0.03^{*}$ & $0.27 \pm 0.02$ & $0.15 \pm 0.01$ & $0.16 \pm 0.01$ & $0.45 \pm 0.03^{*}$ \\
\hline WL, g & $0.10 \pm 0.01^{*}$ & $0.05 \pm 0.01$ & $0.02 \pm 0.003^{*}$ & $0.02 \pm 0.002^{*}$ & $0.11 \pm 0.01$ \\
\hline LWR & $0.18 \pm 0.01$ & $0.18 \pm 0.02$ & $0.15 \pm 0.01$ & $0.10 \pm 0.01$ & $0.27 \pm 0.02$ \\
\hline NI, pc. & $1.93 \pm 0.11$ & $1.79 \pm 0.10$ & $1.38 \pm 0.07$ & $1.59 \pm 0.08$ & - \\
\hline WG, g & $0.02 \pm 0.01$ & $0.06 \pm 0.01$ & $0.03 \pm 0.004$ & $0.03 \pm 0.003$ & $0.08 \pm 0.01$ \\
\hline RE & $0.06 \pm 0.01^{*}$ & $0.25 \pm 0.02$ & $0.22 \pm 0.02$ & $0.19 \pm 0.02$ & $0.21 \pm 0.02$ \\
\hline NF, pc. & $25.26 \pm 1.3$ & $22.9 \pm 1.29$ & $22.37 \pm 1.15$ & $17.45 \pm 0.94$ & $53.30 \pm 4.99^{*}$ \\
\hline NF/sh, pc. & $51.01 \pm 4.6$ & $39.6 \pm 2.81$ & $30.75 \pm 1.83$ & $28.35 \pm 2.00$ & - \\
\hline
\end{tabular}

*the value is significantly differs from the corresponding value of the another CPs

Table 7. Dry aboveground phytomass (W) and yield of aboveground phytomass (Y) of Trifolium repens in different landscape subzones on the territory of the Republic of Tatarstan.

\begin{tabular}{|c|c|c|c|c|}
\hline $\begin{array}{c}\text { Landscape } \\
\text { subzone }\end{array}$ & $\begin{array}{c}\text { CP } \\
\text { No }\end{array}$ & W (mean), g* & $\begin{array}{c}\text { W (error of the } \\
\text { mean), } \mathbf{g}\end{array}$ & $\begin{array}{c}\text { Y, kg of dry } \\
\text { weight/ha* }\end{array}$ \\
\hline \multirow{4}{*}{ Subtaiga } & 1 & $0.13 \mathrm{a}$ & 0.01 & $20.7 \mathrm{a}$ \\
\cline { 2 - 5 } & 2 & $0.31 \mathrm{a}$ & 0.02 & $55.0 \mathrm{a}$ \\
\cline { 2 - 5 } & 3 & $0.25 \mathrm{a}$ & 0.01 & $52.3 \mathrm{a}$ \\
\cline { 2 - 5 } & 4 & $0.22 \mathrm{a}$ & 0.02 & $51.8 \mathrm{a}$ \\
\hline \multirow{5}{*}{ Broad-leaf } & 5 & $0.87 \mathrm{f}$ & 0.17 & $210 \mathrm{c}$ \\
\cline { 2 - 5 } & 6 & $0.19 \mathrm{a}$ & 0.02 & $20.8 \mathrm{a}$ \\
\cline { 2 - 5 } & 7 & $0.49 \mathrm{~d}$ & 0.06 & $40.2 \mathrm{a}$ \\
\cline { 2 - 5 } & 8 & $0.23 \mathrm{a}$ & 0.01 & $30.0 \mathrm{a}$ \\
\cline { 2 - 5 } & 10 & $0.45 \mathrm{~cd}$ & 0.03 & $17.2 \mathrm{a}$ \\
\cline { 2 - 5 } & 11 & $0.70 \mathrm{e}$ & 0.03 & $68.6 \mathrm{a}$ \\
\cline { 2 - 5 } & 12 & $0.27 \mathrm{a}$ & 0.02 & $33.3 \mathrm{a}$ \\
\cline { 2 - 5 } & 13 & $0.15 \mathrm{a}$ & 0.01 & - \\
\hline Forest-steppe & 14 & $0.45 \mathrm{bcd}$ & 0.01 & $\mathrm{a}$ \\
\hline
\end{tabular}

*Note: values accompanied by the same letters differ insignificantly according to the Duncan's criterion.

We found a high positive correlation between the shoot dry biomass and the total yield of dry aboveground phytomass $(\mathrm{R}=0.87 * *)$.

Reliably high values of shoot dry phytomass $(0.7$ and $0.87 \mathrm{~g})$, as well as the total aboveground phytomass (177.5 and $210 \mathrm{~kg} / \mathrm{ha}$ ) were found in CPs 6 and 11, which are common in the forest and grass-forb phytocoenoses in the broad-leaf subzone. In other CPs, the yield of aboveground phytomass varied within the range of $20.7-77.2 \mathrm{~kg} / \mathrm{ha}$ and did not significantly differ among these CPs. 


\section{Discussion}

The density of shoots in the white clover CPs is $15-48 \mathrm{pcs} / \mathrm{m}^{2}$, with the highest density observed in the southern regions of the broad-leaf subzone, and the lowest density noted for northern regions of the broad-leaf subzone. Our studies show that in the northern parts of the broad-leaf subzone, white clover coenopopulations have a high productivity of the aboveground phytomass. Therefore, a decrease in the density of plagiotropic shoots leads to an increase in their phytomass.

The decrease in shoot length, their total biomass, and leaf biomass may be due to the high density of CPs in the south of the broad-leaved subzone.

The analysis of allometric parameters of white clover plants showed that the relative contribution of biomass to photosynthetic effort is higher in the subtaiga subzone (CPs 2 and 4 ), where $L W R=0.25-0.28$, and the lowest values of photosynthetic effort (LWR = $0.01-0.1$ ) were found in the north of the broad-leaved subzone. The contribution of biomass to reproductive organs is comparatively higher in the south of the broad-leaved subzone and in the subtaiga subzone, where $\mathrm{RE}=0.2-0.33$. According to our data, in white clover, the values of reproductive effort have a negative correlation with the biomass and length of shoots $(r=-0.72$, significant at $p=0.05)$, and the values of photosynthetic effort have a negative correlation with the biomass of shoots $(r=-0.6$, significant at $\mathrm{p}=0.05)$. Consequently, with an increase in the total aboveground phytomass of white clover plants, the contribution of phytomass to reproductive organs and leaves decreases.

According to literature data, a decrease of white clover biomass correlates with a high level of accumulation of flavanoids (quercetin glucosides) [10].

In the north of the broad-leaved subzone, under conditions of high humidity soil and medium nitrogen content, of white clover CPs of low density $\left(15-24 \mathrm{pcs} / \mathrm{m}^{2}\right)$ are formed, the generative shoots of plants have the highest dry aboveground phytomass $(0.5-0.9 \mathrm{~g})$ and the largest number of flowers (51-57 pcs. per shoot), the yield of dry aboveground biomass reaches $178-210 \mathrm{~kg} / \mathrm{ha}$. In the south of the broad-leaved subzone and in the forest-steppe subzone, under conditions of a decrease in soil moisture and an increase in the content of mineral nitrogen in them, the density of white clover CPs increases to $41-48 \mathrm{pcs} / \mathrm{m}^{2}$, while the dry aboveground phytomass of generative shoots decreases (to 0.2-0.3 g) and the number of flowers (to $28-40$ pcs. per shoot). The yield of dry aboveground biomass reaches $30-70 \mathrm{~kg} /$ ha only.

\section{Conclusions}

Our studies have shown that the habitat conditions of white clover on the territory of the Republic of Tatarstan in the subtaiga subzone are characterized by slightly acidic soils and fresh moisture content soils with the mineral nitrogen content above average. In the broadleaved subzone, white clover grows on soils from fresh in the north to dry, periodically fresh in the south, the content of mineral nitrogen in them varies from average to above average when moving from north to south subzone. In all habitats, a relationship between the values of ecological scales and the traditional index $\mathrm{pH}$ of salt extract was revealed. Laboratory analyzes of soils showed the highest content of humus and nitrate nitrogen in individual habitats of white clover within the broad-leaved subzone.

According to our data the highest density of shoots $\left(41-48 \mathrm{pcs} . / \mathrm{m}^{2}\right)$ was found in the south of the broad-leaved subzone and in selected habitats of the subtaiga subzone, while the lowest density $\left(15-24 \mathrm{pcs} . / \mathrm{m}^{2}\right)$ was observed in the north of the broad-leaved subzone and in the forest-steppe subzone. In the CPs with shoot density of less than $25 \mathrm{pcs} . / \mathrm{m}^{2}$, the proportion of generative shoots is higher, being over $90 \%$. 
In the investigated of white clover CPs the length of generative plagiotropic shoots is from $3.9-30.3 \mathrm{~cm}$, their dry aboveground phytomass: $0.15-0.87 \mathrm{~g}$, total number of flowers: 15.2-51 pcs. per shoot, the contribution of phytomass to photosynthetic organs and reproductive organs, range from 0.01 to 0.28 and from 0.02 to 0.25 , respectively. The yield of dry aboveground phytomass of white clover in different landscape subzones on the territory of the Republic of Tatarstan is $20-210 \mathrm{~kg} / \mathrm{ha}$. According to the correlation analysis, the parameters of phytomass and shoot length have a positive correlation $(\mathrm{r}=$ 0.94 , significant at $\mathrm{p}=0.01$ ), while reproductive effort has a negative correlation with biomass and shoot length $(\mathrm{r}=-0.72$, significant at $\mathrm{p}=0.05)$, likewise photosynthetic effort with shoot biomass $(\mathrm{r}=-0.6$, significant at $\mathrm{p}=0.05)$.

In the north of the broad-leaved subzone within the Republic of Tatarstan, of white clover CPs have a relatively low density of shoots, which leads to the formation of shoots with a higher phytomass and an increase in the total yield of dry aboveground phytomass of plants. In this regard, white clover CPs growing in the north of the broad-leaved and foreststeppe subzone can be recommended for harvesting as a medicinal raw material.

This work was carried out with the financial support of the Russian Foundation for Basic Research and the Government of the Republic of Tatarstan in the framework of the scientific project No. 18-44160015. This paper has been supported by the Kazan Federal University Strategic Academic Leadership Program.

\section{References}

1. G. Carlsson, K. Huss-Danell, Plant and soil, 253 (2003)

2. A. Elgersma, J. Hassink, Plant and soil, 197 (1997)

3. S. Vrignon-Brenas, F. Celette, C. Amosse, Ch. David, Europ. J. Agronomy, 73 (2016)

4. O.A. Korovkin, Izv. TSHA, 6 (2013)

5. A.V. Abramchuk, M.Ju. Karpuhin, Vestnik biotechnology, 20, 16 (2019)

6. A.A. Drenin, Je.H. Botirov, Plant chemistry, 3 (2017)

7. J. Kolodziejczyk-Czepas, J. of Ethnopharmacology, 143 (2012)

8. O.P. Ermolaev, M.E. Igonin, Georesursy, 19 (2006)

9. A.P. Schaffers, K.V. Sykora, J. Veg. Sc., 11 (2000)

10. R.W. Hofmann, M.Z. Zulfighar Jahufer, PLoS ONE, 6, 4 (2011) 